\title{
APAKAH SIKAP MAMPU MEMODERASI HUBUNGAN ANTARA DUKUNGAN DAN KINERJA MANAJEMEN RISIKO?
}

\author{
Vincent Valerian \\ Lembaga Sertifikasi Profesi Manajemen Risiko - LSPMR \\ koetjai@gmail.com \\ Yosia Moelyono \\ Lembaga Sertifikasi Profesi Manajemen Risiko - LSPMR \\ moelyonoyosia@gmail.com \\ Ronny Kountur \\ PPM School of Managementa \\ RON@ppm-manajemen.ac.id
}

\begin{abstract}
ABSTRAK
Tujuan dari penelitian ini adalah untuk mengetahui apakah sikap manajemen dapat memoderasi hubungan antara dukungan manajemen dan kinerja manajemen risiko. Responden dari 112 perusahaan diambil. Mereka adalah manajemen risiko tingkat atas di perusahaan-perusahaan tersebut. Angket dirancang untuk mengumpulkan data. Validitas dan reliabilitas dari kuesioner telah diuji. Teknik analisis regresi berganda digunakan untuk menguji hipotesis nol bahwa sikap merupakan variabel moderasi antara dukungan manajemen dan kinerja manajemen risiko. Hipotesis nol diterima yang menunjukkan bahwa sikap terhadap manajemen risiko bukan variabel moderasi dalam hubungan antara dukungan manajemen dan kinerja manajemen risiko. Namun analisis lebih lanjut dengan menggunakan analisis jalur menemukan bahwa dukungan manajemen adalah variabel mediasi antara sikap dan kinerja manajemen risiko. Karena itu, ketika manajemen puncak memiliki sikap positif terhadap manajemen risiko akan meningkatkan kinerja manajemen risiko organisasi.
\end{abstract}

Kata kunci:

Manajemen risiko, sikap, dukungan manajemen, kinerja manajemen risiko.

\begin{abstract}
The purpose of this study is to know whether management attitudes can moderate the relationship between management support and risk management performance. Respondents from 112 companies were taken. They were the top rank risk management personal in those companies. Questionnaire was designed in collecting the data. The validity and reliability of the questionnaire has been tested. Multiple regression analysis techniques were used to test the null hypothesis that attitude is the moderating variable between management support and risk management performance. The null hypothesis was accepted indicating that attitude toward risk management was not a moderating variable in the relationship between management support and risk management performance. However further analysis with the use of path analysis found that management support instead was the mediating variable between attitudes and performance of risk management. Therefore, when top management has positive attitude toward risk management will increase the risk management performance of the organization.
\end{abstract}

Keywords:

Risk management, attitude, management support, risk management performance. 


\section{PENDAHULUAN}

Saat ini risiko tidak hanya dipandang dari sisi finansial untuk menghindari perusahaan dari kebangkrutan namun juga dari segi non financial yang dapat menaikkan nilai intrinsik dari suatu perusahaan. Penelitian membuktikan bahwa kinerja manajemen risiko yang baik akan meningkatkan nilai saham perusahaan (Farrell dan Gallagher 2015; Lai, Fong-Woon, \& Samad 2010). Perlu diketahui bahwa risiko mempengaruhi kinerja perusahaan dan ada banyak risiko yang dapat mempengaruhi kinerja perusahaan. Studi yang dilakukan CRMS (Center for Risk Management Studies, 2017) menemukan bahwa risiko reputasi merupakan risiko yang dianggap paling mengancam keberlangsungan perusahan, diikuti dengan kegagalan perencanaan SDM. Dalam survei yang sama, kepemimpinan dan komitmen manajer senior merupakan hambatan terbesar dalam mengimplementasikan manajemen risiko. Sebanyak $69 \%$ dari responder memilih hal tersebut sebagai hambatan terbesar.

Ada korelasi yang positif antara dukungan manajemen (management support) dari chief executive officer dan chief financial officer dan implementasi enterprise risk management (ERM (Beasley, Clune \& Hermanson, 2005; Sprčić, Kožul, \& Pecina, 2017). Telah banyak penelitian yang dilakukan yang menunjukkan bahwa kesuksesan suatu pekerjaan ditentukan oleh dukungan manajemen (Dewi, 2013; Mahoney, 2011; McComb dan kawan-kawan, 2008; Young dan Jordan, 2008; Beasley dan kawankawan, 2015; Togok, 2016; Sprcic dan kawankawan, 2017). Sementara sikap terhadap sesuatu dapat menentukan apakah akan memperkuat atau memperlemah dukungan (Fishbein \& Ajzen's, 1975). Namun sikap juga dapat dipengaruhi oleh perilaku. Biasanya jika orang tidak mengerti akan sesuatu, maka orang tersebut akan bertindak terlebih dahulu, untuk mengambil sikap di belakang, sambil melihat situasi apakah yang diperbuatnya menguntungkan atau tidak menguntungkan (Simamora, 2002).

Belum ada penelitian yang membahas mengenai dukungan manajemen terhadap kinerja manajemen risiko, juga belum ada penelitian khusus yang melihat sikap dari manajemen terhadap manajemen risiko itu sendiri, termasuk sikap manajemen sebagai 
variabel moderator antara dukungan

manajemen dengan kinerja manajemen risiko

itu sendiri. Dengan demikian ada kesenjangan pengetahuan (knowledge gap) sehingga penelitian perlu dilakukan. Tujuan dari penelitian ini adalah untuk mengetahui apakah sikap mampu menjadi variabel moderator antara dukungan manajemen dan kinerja manajemen risiko.

\section{TINJAUAN}

TEORI

DAN

\section{PENGEMBANGAN HIPOTESIS}

\section{Dukungan Manajemen}

Terdapat lima faktor yang menjadi dimensi dari dukungan manajemen. Berikut adalah dimensi-dimensi dari dukungan manajemen menurut Mahoney (2011) dan Boonstra (2013). Yang pertama adalah memantau rencana dan kemajuan program, termasuk menghadiri rapat steering committee. Manajemen bertugas untuk melakukan pemantauan antara rencana dan progres (kemajuan) yang sedang terjadi pada saat program atau proyek berjalan. Manajemen harus menjaga agar program atau proyek dapat berjalan tepat waktu dan tepat biaya sesuai perencanaan awal. Hal ini diungkapkan oleh Nah (2001); Young dan Jordan (2008); Dong dan kawan-kawan (2009); Staehr (2010);

Boonstra (2013). Kedua adalah mengkomunikasikan tujuan dari program. Manajemen harus aktif berkomunikasi mengenai tujuan dan sasaran dari program atau proyek tertentu. Komunikasi ini harus dilakukan kepada pimpinan proyek, karyawan perusahaan yang terlibat di dalam proyek, pemegang kepentingan, bahkan jika perlu mengkomunikasikan tujuan proyek kepada pelanggan. Hal ini diungkapkan oleh Loonam dan McDonagh (2005); Young dan Jordan (2008); Dong dan kawan-kawan (2009); Dewi dan Dwirandra (2013); Boonstra (2013). Ketiga, menyediakan sumber daya (uang, manusia, perhatian). Manajemen bertugas untuk menyediakan dan mengatur sumber daya yang diperlukan untuk mensukseskan suatu program atau proyek. Hal ini diungkapkan oleh Loonam dan McDonagh (2005); Young dan Jordan (2008); Dong dan kawan-kawan (2009); Young dan Poon (2012); Dewi dan Dwirandra (2013); Boonstra (2013). Keempat, menggunakan kekuasaannya untuk membuat perubahan yang diperlukan. Manajemen memiliki kekuasaan karena mereka berada pada pucuk kepemimpinan dari suatu perusahaan. Oleh karena itu mereka 
harus menggunakan kekuasaannya untuk melakukan perubahan dan menolak resistensi perubahan. Hal ini sesuai dengan penelitian dari Loonam dan McDonagh (2005); Young dan Jordan (2008); Dong dan kawan-kawan (2009); Young dan Jordan (2008); Young dan Poon (2012); Boonstra (2013). Kelima, berusaha menjadi ahli di bidangnya. Biasanya orang-orang yang sudah menduduki manajemen adalah orang-orang yang memang ahli pada bidang tersebut. Namun tidak jarang terjadi kalau ada satu atau dua ilmu yang tidak dikuasai sehingga perlu dipelajari lebih lanjut. Kualitas pengetahuan dari manajemen menjadi salah satu faktor kunci keberhasilan program atau proyek. Hal ini sesuai dengan penelitian oleh Ehsani dan kawan-kawan 2013; Yazid dan kawan-kawan 2013; Boonstra (2013). Jadi, 5 faktor dimensi yang menunjukkan dukungan manajemen adalah memantau rencana dan kemajuan program, mengkomunikasikan tujuan dari program, menyediakan sumber daya (uang, manusia, waktu atau perhatian), menggunakan otoritasnya untuk membuat perubahan yang diperlukan, dan berusaha menjadi ahli di bidangnya.

\section{Sikap}

Schifman dan Kanuk dalam Simamora (2002) menyatakan bahwa sikap adalah ekspresi perasaan yang mencerminkan apakah seseorang senang atau tidak senang, suka atau tidak suka, dan setuju atau tidak terhadap suatu objek. Objek yang dimaksud bisa berupa merek, layanan, perilaku tertentu, dan lainlain. Jika Schifman dan Kanuk memandang sikap dari segi perasaan, maka Alport (1996) menyatakan sikap sebagai predisposisi yang dipelajari untuk berespons terhadap suatu objek dalam suasana menyenangkan atau tidak menyenangkan secara konsisten (Simamora, 2002).

Sikap, secara umum didefinisikan sebagai pengaruh atau penolakan, penilaian, suka atau tidak suka, atau kepositifan atau kenegatifan terhadap suatu obyek psikologis (Muller, 1992). Paul dan Olson (1999) menyatakan bahwa sikap adalah evaluasi konsep secara menyeluruh yang dilakukan oleh seseorang (Simamora, 2002). Sikap merupakan komponen penting dalam jiwa manusia yang akan mempengaruhi perilaku seseorang. Sikap mempengaruhi segala keputusan yang kita ambil maupun yang kita pilih. Sikap kita akan mempengaruhi siapa 
teman hidup yang kita pilih, baju yang kita sukai, hobi yang akan kita tekuni. Singkatnya, sikap mempengaruhi kehidupan kita seharihari.

Sikap mempunyai empat karakteristik yaitu sikap selalu memiliki objek, sikap selalu memiliki arah derajat dan intensitas, sikap mempunyai struktur, dan kerangka dari beberapa sikap yang ada pada seseorang, dan sikap merupakan proses yang dipelajari (Simamora, 2002).

Para ahli psikologi sosial menganggap bahwa sikap terdiri dari tiga komponen. Komponen pertama adalah komponen kognitif yaitu pengetahuan dan keyakinan seseorang mengenai sesuatu yang menjadi objek sikap (Simamora, 2002). Misalnya Ani yakin bahwa memakan buah dapat melancarkan pencernaan. Komponen kedua adalah komponen afektif. Ini berisikan perasaan terhadap objek sikap (Simamora, 2002). Misalnya, Ani suka terhadap buah mangga. Komponen ketiga adalah komponen konatif yaitu kecenderungan melakukan sesuatu terhadap objek sikap (Simamora, 2002). Misalnya, Ani akan membeli buah mangga. Ketiga komponen tersebut berada dalam suatu hubungan yang konsisten. Sebelum suka atau tidak suka (komponen afektif) terhadap suatu objek, tentu seseorang harus tahu dan yakin lebih dahulu (komponen kognitif). Seseorang membeli suatu produk (komponen konatif), tentu karena suka (komponen afektif), kecuali dalam keadaan terpaksa (Simamora, 2002). Pengukuran dari sikap selalu merujuk pada kekuatan dari komponen afektif. Secara fakta, skala pemeringkatan selalu dihitung berdasarkan intensitas dari perasaan seseorang terhadap suatu objek (Katz, 1960). Sehingga pada penelitian ini, penulis memfokuskan pengukuran pada komponen afektif saja dari sikap.

Salah satu teori yang berkembang mengenai alasan seseorang melakukan sesuatu adalah teori alasan bertindak yang dicetuskan oleh Fishbein and Ajzen's (1975). Alasan seseorang melakukan sesuatu adalah karena didorong oleh sikap dan norma subjektif yang dipercayai oleh orang tersebut. Mereka menyatakan bahwa sikap seseorang terhadap perilaku dapat diprediksi dengan menghitung hasil evaluasi yang dibuat berdasarkan setiap konsekuensi perbuatan dengan tingkat kepercayaan bahwa pada tahap tertentu, konsekuensi dari perilaku yang dilakukan mengarah pada konsekuensi yang dipercayai 
oleh orang tersebut. Hasil dari perlilaku dan konsekuensi perlilaku ini akan menjadi sikap orang tersebut. Sikap akan menjadi suatu kepercayaan yang melogiskan seseorang untuk melakukan perilaku tertentu menurut orang tersebut.

Kelemahan dari teori alasan bertindak adalah saat seseorang berperilaku yang tidak sesuai dengan kepercayaan yang dimiliki olehnya. Pada saat itu, teori perilaku terencana berkembang. Teori yang diungkapkan oleh Ajzen pada tahun 1991 menyatakan bahwa alasan seseorang melakukan sebuah perilaku, bukan hanya berdasarkan sikap dan norma subjektif yang dipercayai oleh orang tersebut. Tapi juga berdasarkan kontrol perilaku yang disadari oleh orang tersebut. Kontrol perilaku yang dibuat oleh seseorang biasanya berdasarkan pengalaman hidup masa lalu dan keadaan sosial di mana seseorang tersebut hidup dan bertumbuh. Maka dari itu, perilaku yang tidak sesuai dengan sikap dan kepercayaan dapat timbul dan sikap dapat berubah sesuai dengan kebiasaan dan pengalaman yang dialami oleh seseorang

Tidak setiap saat sikap dan perilaku seseorang berjalan beriringan. Ada saat-saat di mana seseorang berperilaku tidak sesuai dengan sikap atau kepercayaan yang dianutnya. Teori ini dicetuskan oleh Leon Festinger pada tahun 1957. Pada saat perilaku seseorang tidak sesuai dengan sikapnya, maka akan terjadi ketidaknyamanan dalam diri orang tersebut. Orang tersebut akan mencoba untuk mengubah perilakunya atau mencoba untuk mengubah sikap dan kepercayaannya agar sesuai dengan perilaku yang dia lakukan. Contoh yang paling populer dari teori ini adalah seorang perokok aktif yang mengetahui bahwa merokok dapat menyebabkan penyakit. Perokok ini akan mengubah perilakunya untuk mencoba berhenti merokok atau mencoba untuk membenarkan pikirannya bahwa merokok dapat menyebabkan penyakit, namun dalam jangka waktu yang amat lama. Teori ini mendukung penelitian bahwa sikap dapat bertentangan dengan perilaku. Contoh yang relevan terjadinya pertentangan ini adalah manajemen yang mendukung penerapan manajemen risiko pada sebuah perusahaan, namun memiliki sikap yang negatif. Sehingga yang dapat terjadi adalah dukungan yang diberikan menjadi setengah hati (mendukung karena sekedar mengikuti aturan saja). Hal ini dapat menyebabkan kinerja manajemen risiko menjadi tidak maksimal. 


\section{Kinerja Manajemen Risiko}

Dibutuhkan suatu cara untuk mengukur seberapa baik manajemen risiko telah diterapkan. Terdapat berbagai macam cara untuk mengukur kinerja dari manajemen risiko, namun cara-cara ini tidak distandardisasikan, atau tidak ada suatu cara baku yang menjadi standar acuan bagi pengukuran kinerja manajemen risiko. Manajemen risiko adalah suatu ilmu yang masih belum matang di dalam ilmu manajemen itu sendiri, bagaimana cara mengukur variabel, efektifitas, desain, dan efek-efek dari setiap langkah dalam manajemen risiko belum dapat diukur secara gamblang (Bromiley, McShane, Nair and Rustambekov, 2015). Terdapat ketidaksepakatan dan bukti-bukti yang kurang lengkap tentang sejauh mana manajemen risiko efektif untuk mengatur risiko perusahaan dan sejauh mana manajemen risiko diterapkan secara efektif (Togok, S. H. 2016). Pada paragraf berikutnya akan dijelaskan beberapa cara untuk mengukur kinerja dari manajemen risiko.

\section{RIMS (Risk Management Society)} membuat suatu pengukuran untuk menilai kinerja, atau yang disebut maturitas dari manajemen risiko. RIMS menilai 7 indikator dari kegiatan-kegiatan yang dilakukan perusahaan terkait manajemen risiko. Kegiatan-kegiatan ini harus berulang, berkelanjutan, dan diketahui oleh seluruh perusahaan. (www.riskmaturitymodel.org) Nilai-nilai ini akan diformulasikan untuk mendapat satu nilai akhir di mana maturitas dari penerapan manajemen risiko dinilai. Semakin matang, maka perusahaan dapat dikatakan mengimplementasikan program manajemen risiko dengan baik. Salah satu yang menggunakan metode ini adalah Farrel dan Gallagher (2014). Mereka menggunakan penilaian maturitas manajemen risiko dari RIMS dan membandingkannya dengan kenaikan nilai saham dari perusahaan yang menerapkan manajemen risiko.

\section{COSO (Comitee Of Sponsoring} Organization of the treadway commission) hanya menjelaskan bahwa perusahaan yang penerapan manajemen risikonya baik dapat mendefinisikan kemampuan dari manajemen risiko untuk menghadapi risiko berdasarkan risk appetite dan risk capacity. Perusahaan yang tidak menerapkan dengan baik akan memiliki pengertian dan definisi yang berbeda dengan definisi yang lebih lebar atau umum 
mengenai risiko yang dihadapi perusahaan. Peneliti yang melihat tentang sejauh mana manajemen risiko telah diterapkan membuat suatu indeks pengukuran sendiri yang berbeda antara satu dengan lainnya. Beasley, Clune dan Hermanson (2005) secara gamblang menanyakan level dari penerapan manajemen risiko kepada responden sehingga hanya ada 5 tingkat penerapan manajemen risiko dari tidak ada penerapan hingga penerapan yang sudah lengkap. Namun dengan menanyakan langsung penerapan manajemen risiko ditakutkan terjadi bias di mana responden menilai terlalu tinggi atau terlalu rendah sehingga penilaian tidak objective Sprčić, D. M., Kožul, A., \& Pecina, E. (2017). Gordon dan kawan-kawan (2009) mencoba untuk membuat suatu indeks pengukuran penerapan manajemen risiko berdasarkan kerangka kerja dari COSO 2004. Mereka membagi pengukuran kinerja manajemen risiko menjadi 4 bagian besar, yaitu strategi, operasional, pelaporan dan kepatuhan. Cara untuk mengukur kinerja manajemen risiko juga telah ditiru oleh Sprčić, D. M., Kožul, A., \& Pecina, E. (2017). Togok, S. H. (2016) juga membuat suatu indeks pengukuran sendiri untuk mengukur kinerja manajemen risiko.
Kuesionernya terdiri dari dua bagian. Bagian pertama menanyakan tentang efektifitas penerapan manajemen risiko berdasarkan ISO 31000. Sedangkan bagian kedua dari kuesioner menanyakan tentang pencapaian manajemen risiko berdasarkan tujuan penerapan manajemen risiko yang didasarkan dari kerangka COSO 2004.

Sampai saat ini belum ada pengukuran yang baku dan diakui secara internasional mengenai penerapan manajemen risiko. Penelitian-penelitian sebelumnya mencoba untuk membuat indeks pengukuran sendiri mengenai efektifitas penerapan manajemen risiko. Beberapa konsultan juga membuat suatu indeks maturitas untuk mengukur sejauh mana pencapaian penerapan manajemen risiko. Beberapa penelitian sudah membuktikan bahwa dengan angka efektifitas penerapan manajemen risiko yang lebih baik, nilai saham dari perusahaan juga lebih tinggi (Waweru dan Kisaka, 2013) \& (Farrel dan Gallagher, 2014). Untuk mengukur kinerja manajemen risiko penulis akan menggunakan kerangka dari COSO 2004 yang menjadi acuan penelitian terbaru Sprčić dan Togok. Penelitian Sprčić dan Togok yang terbaru pada tahun 2016 mengemukakan bahwa 4 dimensi 
pengukuran kinerja manajemen risiko adalah dari segi strategi, operasional, pelaporan dan kepatuhan.

\section{Kerangka Konseptual}

Dalam penelitian ini variabel independen adalah dukungan manajemen serta sikap manajemen sebagai variabel moderasi. Sedangkan variabel dependennya adalah kinerja manajemen risiko. Kerangka konseptual untuk merumuskan hipotesis pada penelitian ini tertera pada gambar 1.

\section{Hipotesis}

Hipotesis pertama, dukungan manajemen berpengaruh terhadap kinerja manajemen risiko. Hipotesa kedua, sikap manajemen mampu memoderasi hubungan dukungan manajemen dengan kinerja manajemen risiko.

\section{METODE RISET}

Penelitian ini merupakan penelitian dasar dengan menggunakan teknik survey di mana menggunakan kuesioner sebagai alat pengumpulan data. Berdasarkan waktu pengambilan datanya, penelitian ini merupakan cross-sectional study. Unit analisis pada penelitian ini adalah perusahaanperusahaan di mana kuesioner diisi oleh jajaran manajemen yang telah memperoleh

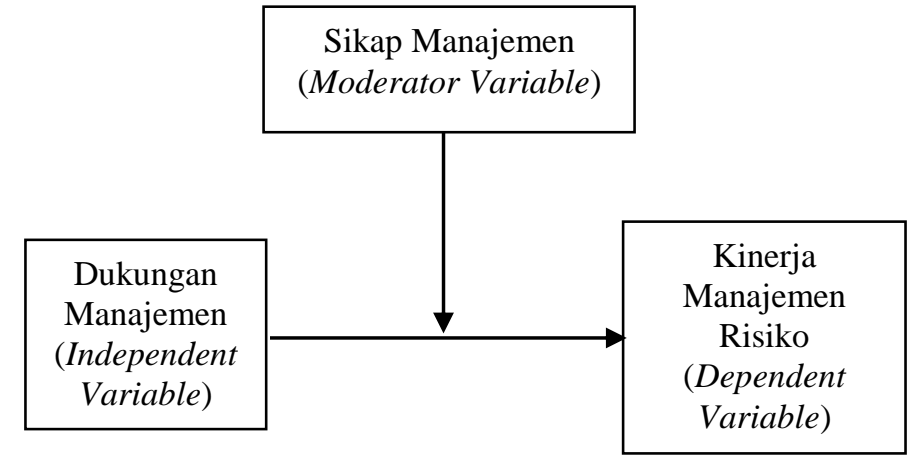

Gambar 1. Kerangka Konseptual

sertifikasi manajemen risiko dari Lembaga Sertifikasi Profesi Manajemen Risiko di Indonesia. Sampling menggunakan cara convenience sampling. Ada sebanyak 112 orang responden yang mewakili perusahaan terdiri dari $4 \%$ dari perusahaan kecil, $27 \%$ dari perusahaan sedang dan $70 \%$ dari perusahaan besar. Responden adalah didominasi oleh BUMN di mana berjumlah 54\%, PMDN (Penanaman Modal Dalam Negeri) sebanyak $32 \%$, Joint Venture sebanyak $12 \%$ responden, dan PMA (Penanaman Modal Asing) sebanyak $3 \%$ dari total keseluruhan responden.

Dalam penyebaran kuesioner tersebut, penulis bekerja sama dengan Lembaga Sertifikasi Profesi Manajemen Risiko (LSPMR) Indonesia. Dalam penyelenggaraan sertifikasi di LSPMR terdapat beberapa level sertifikasi. Kuesioner disebarkan untuk level CRMP dan level CRGP di mana peserta sertifikasi pada level tersebut adalah 
manajemen pada tingkat manajer unit, staf ahli manajemen risiko (risk specialist) dan tingkat manajemen senior (direktur dan presiden direktur) pada perusahaan-perusahaan di Indonesia. Kuesioner ini berisi pertanyaanpertanyaan mengenai persepsi responden tentang sikap manajemen, dukungan manajemen dan kinerja manajemen risiko di perusahaan tempat mereka bekerja.

Untuk mengetahui validitas pada penelitian ini, item tes yang tidak lolos uji akan dibuang dan tidak digunakan. Total pertanyaan yang diuji adalah sebanyak 30 butir pertanyaan. Pembagian 30 butir pertanyaan adalah 10 pertanyaan pada bagian B (sikap), 10 pertanyaan pada bagian $\mathrm{C}$ (dukungan) dan 10 pertanyaan pada bagian $\mathrm{D}$ (kinerja manajemen risiko). Uji reliabilitas dilakukan untuk mengetahui tingkat konsistensi jawaban instrumen. Rangkuman dari hasil uji reliabilitas dari penelitian ini tertera pada tabel 1 .

Pada penelitian ini terdapat 2 hipotesis. Hipotesis pertama adalah dukungan manajemen berpengaruh terhadap kinerja manajemen risiko. Hipotesis ini diselesaikan dengan metode simple regression dengan persamaan:
Tabel 1. Hasil Uji Reliabilitas Kuesioner

\begin{tabular}{|l|c|c|c|}
\hline \multicolumn{1}{|c|}{ Bagian } & $\begin{array}{c}\text { Jumlah } \\
\text { Item }\end{array}$ & $\begin{array}{c}\text { Nilai } \\
\text { Cronbach's } \\
\text { Alpha }\end{array}$ & Hasil \\
\hline B (Sikap) & 7 & 0,848 & Reliabel \\
\hline C (Dukungan) & 7 & 0,818 & Reliabel \\
\hline $\begin{array}{l}\text { D (Kinerja } \\
\text { Manajemen } \\
\text { Risiko) }\end{array}$ & 7 & 0,997 & Reliabel \\
\hline
\end{tabular}

$$
\mathrm{Y}=\mathrm{a} 1+\mathrm{b} 1 \mathrm{X} 1+\mathrm{e}
$$

Keterangan:

$\mathrm{Y}=$ Koefisien Kinerja manajemen risiko

$\mathrm{A}=$ Konstanta

b1= Koefisien Dukungan Manajemen

$\mathrm{X} 1=$ Variabel Dukungan Manajemen

$\mathrm{e}=$ Standard Error

Sedangkan hipotesis 2 adalah sikap manajemen mampu memoderasi hubungan dukungan manajemen dengan kinerja manajemen risiko. Untuk menyelesaikan hipotesis tersebut maka persamaan regresi yang dapat dibentuk adalah sebagai berikut:

$$
\mathrm{Y}=\mathrm{a} 1+\mathrm{b} 1 \mathrm{X} 1+\mathrm{e}
$$

(tanpa melibatkan variabel moderator)

$$
\mathrm{Y}=\mathrm{a} 2+\mathrm{b} 1 \mathrm{X} 1+\mathrm{b} 2 \mathrm{X} 2+\mathrm{e}
$$

(melibatkan variabel moderator)

$\mathrm{Y}=\mathrm{a} 3+\mathrm{b} 1 \mathrm{X} 1+\mathrm{b} 2 \mathrm{X} 2+\mathrm{b} 3 \mathrm{X} 1 \mathrm{X} 2+\mathrm{e}$

(melibatkan variabel moderator dan variabel interaksi) 
Keterangan :

$\mathrm{Y}=$ Koefisien Kinerja manajemen

risiko

$\mathrm{a}=$ Konstanta

b1 = Koefisien Dukungan Manajemen

b2 = Koefisien Sikap Manajemen

b3 = Koefisien Interaksi Sikap

Manajemen

* Dukungan Manajemen

$\mathrm{X} 1$ = Variabel Dukungan Manajemen

X2 = Variabel Sikap Manajemen

$\mathrm{e}=$ Standard Error

\section{HASIL}

PENELITIAN

DAN

\section{PEMBAHASAN}

Apakah sikap manajemen merupakan moderasi antara hubungan dukungan manajemen dengan kinerja manajemen risiko? Null hipotesis pertama, dukungan manajemen tidak berpengaruh terhadap kinerja manajemen risiko. Regresi linear digunakan untuk menguji null hipotesa ini. Persamaan regresi yang signifikan ditemukan dengan $F(1,110)=$ $328,302, \mathrm{P}<0,001$ dan $\mathrm{R}$-square $=0.749$. Persamaan regresi untuk dukungan manajemen risiko adalah $1,172+1,133$ (avgC), di mana avgC adalah dukungan manajemen terhadap manajemen risiko.
Kinerja manajemen risiko meningkat sebesar 1,133 (dari skala 7) untuk setiap kenaikan nilai dari dukungan manajemen. Dukungan manajemen terhadap manajemen risiko adalah prediktor yang signifikan untuk kinerja manajemen risiko.

Selanjutnya akan dilakukan pengujian untuk melihat efek moderasi variabel sikap. Sebelum melakukan pengujian ini, terdapat syarat yang harus dipenuhi sebelum melakukan regresi yaitu data berdistribusi normal dan tidak terdapat outlier. Uji normalitas bertujuan untuk menguji apakah dalam model regresi, variabel pengganggu atau residual memiliki distribusi normal. Uji normalitas dilakukan dengan menggunakan uji Kolmogorov-Smirnov dengan kaidah jika signifikan $\geq 0,05$, maka dapat dikatakan data tersebut berdistribusi normal. Berdasarkan uji normalitas dengan menggunakan Kolmogorov-Smirnov Test diperoleh nilai Asymp. Sig. sebesar 0,328 >0,05. Maka dapat disimpulkan bahwa data berdistribusi normal. Kemudian untuk memenuhi syarat selanjutnya yaitu tidak adanya outlier, plot box menunjukkan bahwa data tidak memiliki outlier. Hal ini berarti sudah memenuhi syarat dan hasil pengolahan menggunakan regresi 
linier dapat dilakukan lebih lanjut. Berikut adalah hasil pengolahan untuk melihat variabel moderasi dengan menggunakan SPSS:

Regresi linear digunakan untuk memprediksi kinerja manajemen risiko berdasarkan faktor sikap manajemen, dukungan manajemen dan interaksi antara sikap dan dukungan. Pada tabel di atas, tidak ditemukan persamaan regresi yang signifikan dengan $\mathrm{F}(3,108)=119,035, \mathrm{P}<0,001$ dan $\mathrm{R} 2=$ 0.761. Sikap manajemen, dukungan manajemen, dan interaksi antara sikap dan dukungan, ketiganya bukan merupakan prediktor yang signifikan untuk kinerja manajemen risiko jika digabungkan. Maka pengujian moderasi tidak dapat dilanjutkan.

Kerangka konseptual yang dibangun untuk terdapat pada gambar 2 (variabel dukungan sebagai mediasi antara sikap dan kinerja manajemen risiko).
Tabel 2. Hasil Olah Data SPSS - Uji R Square (Koefisien Determinasi)

\begin{tabular}{|l|c|l|l|l|}
\hline Model & R & R Square & $\begin{array}{l}\text { Adjusted } \\
\text { R Square }\end{array}$ & $\begin{array}{l}\text { Std. Error of } \\
\text { the Estimate }\end{array}$ \\
\hline 1 & $.876^{\mathrm{a}}$ & .768 & .761 & .313 \\
\hline
\end{tabular}

a. Predictors: (Constant), AvgB*AvgC, AvgC, AvgB

b. Dependent Variable: TotD

Tabel 3. Hasil Olah Data SPSS - Regresi Linear Efek Moderasi

\begin{tabular}{|l|l|l|l|l|c|c|}
\hline \multicolumn{2}{|c|}{ Model } & $\begin{array}{c}\text { Sum of } \\
\text { Square }\end{array}$ & df & $\begin{array}{c}\text { Mean } \\
\text { square }\end{array}$ & F & Sig. \\
\hline 1 & Regression & 34.880 & 3 & 11.627 & 119.035 & .000 \\
\hline & Residual & 10.549 & 108 & .098 & & \\
\hline & Total & 45.429 & 111 & & & \\
\hline
\end{tabular}

Tabel 4. Hasil Olah Data SPSS - Uji

Koefisien

\begin{tabular}{|c|c|c|c|c|c|c|}
\hline \multirow{2}{*}{\multicolumn{2}{|c|}{ Model }} & \multicolumn{2}{|c|}{$\begin{array}{c}\text { Unstandar } \\
\text { dized } \\
\text { Coefficients }\end{array}$} & $\begin{array}{c}\text { Standardized } \\
\text { Coefficients }\end{array}$ & \multirow[t]{2}{*}{$\mathbf{t}$} & \multirow[t]{2}{*}{ Sig. } \\
\hline & & B & $\begin{array}{c}\text { Std. } \\
\text { Erro } \\
\mathbf{r}\end{array}$ & Beta & & \\
\hline 1 & $\begin{array}{l}\text { (Consta } \\
\mathrm{nt})\end{array}$ & $\begin{array}{l}4.10 \\
1\end{array}$ & $\begin{array}{l}1.10 \\
2\end{array}$ & & $\begin{array}{l}3 . \\
72 \\
1\end{array}$ & .000 \\
\hline & AvgC & .256 & .305 & .196 & $\begin{array}{l}.8 \\
40\end{array}$ & .403 \\
\hline & AvgB & -.708 & .293 & -.597 & $\begin{array}{l}- \\
2 . \\
41 \\
1\end{array}$ & .018 \\
\hline & $\begin{array}{l}\text { AvgB* } \\
\text { Avg }\end{array}$ & .210 & .075 & 1.204 & $\begin{array}{l}2 . \\
79 \\
0\end{array}$ & .006 \\
\hline & C & & & & & \\
\hline
\end{tabular}

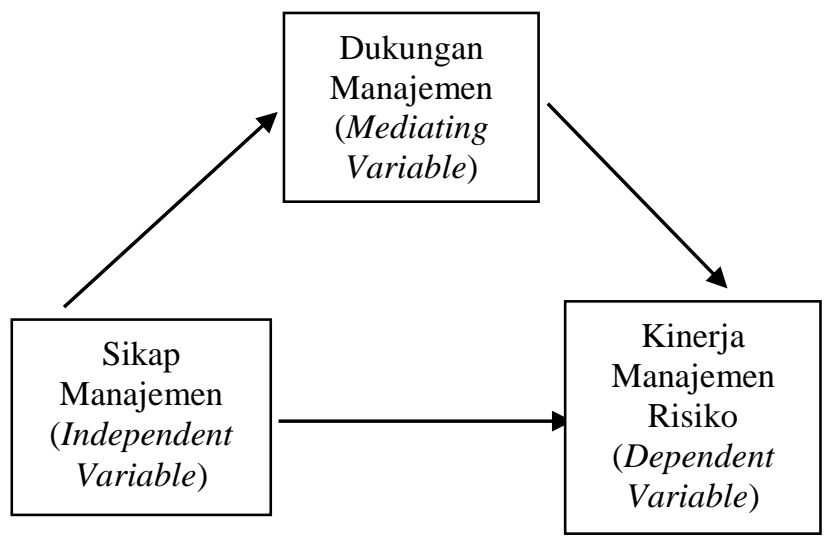

Gambar 2. Kerangka Konseptual Dengan Dukungan Sebagai Variabel Mediasi 
Pengukuran variabel mediasi ini menggunakan uji regresi. Istilah lain uji regresi dengan variabel intervening adalah path analysis atau analisis jalur. Analisis regresi biasa digunakan untuk menguji apakah ada pengaruh langsung yang diberikan oleh variabel independen terhadap variabel dependen. Sementara analisis jalur tidak hanya menguji pengaruh langsung saja, tetapi juga menjelaskan tentang pengaruh tidak langsung yang diberikan variabel independen melalui variabel mediasi terhadap variabel dependen. Untuk mendeteksi peran mediator, maka langkah-langkah dalam menguji hipotesis mengacu pada prosedur pengujian peran mediator yang dikemukakan oleh Baron dan Kenny (1986) sebagai berikut: (1) Membuat persamaan regresi sikap (AvgB) terhadap kinerja manajemen risiko (TotD). Jalur ini diharapkan signifikan $(\mathrm{p}<0,05)$; Membuat persamaan regresi sikap (AvgB) terhadap dukungan (AvgC). Jalur ini diharapkan signifikan $(\mathrm{p}<0,05)$; Dan (3) Membuat persamaan regresi sikap (AvgB) dan dukungan $(\mathrm{AvgC})$ terhadap kinerja manajemen risiko (TotD). Analisis regresi ini akan menghasilkan dua nilai estimasi prediktor dari AvgC dan AvgB. Prediksi AvgC terhadap
TotD diharapkan signifikan $\quad(p<0,05)$, sedangkan prediksi $\mathrm{X}$ terhadap $\mathrm{Y}$ diharapkan tidak signifikan $(\mathrm{p}>0,05)$.

Jika pengaruh sikap ke kinerja manajemen risiko menurun menjadi nol setelah memasukkan dukungan ke persamaan regresi (atau tidak signifikan), maka terjadi mediasi sempurna (perfect mediation). Namun jika efek variabel independen ke dependen menurun namun tidak sama dengan nol dengan memasukan mediator (atau signifikan), maka terjadi mediasi parsial.

Pertama, pengaruh yang akan diuji adalah pengaruh sikap terhadap kinerja manajemen risiko.

Regresi linear digunakan untuk memprediksi kinerja manajemen risiko berdasarkan faktor sikap manajemen. Persamaan regresi yang signifikan ditemukan dengan $\mathrm{F}(1,110)=$ 88.915, $\mathrm{P}<0,001$ dan $\mathrm{R} 2=0.447$. Persamaan regresi untuk kinerja manajemen risiko adalah $2,394+0,792(\operatorname{avgB})$, di mana avgB adalah sikap manajemen terhadap manajemen risiko. Kinerja manajemen risiko meningkat sebesar 0,792 (dari skala 7) untuk setiap kenaikan nilai dari sikap manajemen. Sikap manajemen terhadap manajemen risiko adalah prediktor 


\begin{tabular}{|c|c|}
$\begin{array}{c}\text { Sikap } \\
\text { Manajemen } \\
\text { (Independent } \\
\text { Variable })\end{array}$ & $\longrightarrow$ \\
$\begin{array}{c}\text { Kinerja } \\
\text { Manajemen } \\
\text { Risiko } \\
\text { (Dependent } \\
\text { Variable })\end{array}$ \\
\hline
\end{tabular}

Gambar 3. Pengaruh Sikap Terhadap Kinerja Manajemen Risiko

yang signifikan untuk kinerja manajemen risiko.

Pada hasil sebelumnya, dijelaskan bahwa sikap secara signifikan mempengaruhi kinerja manajemen risiko, sehingga kriteria pertama terpenuhi. Selanjutnya, yang kedua adalah hasil output setelah data diolah menggunakan SPSS untuk menyelesaikan persamaan kedua yaitu dengan menguji pengaruh sikap terhadap dukungan. Regresi linear digunakan untuk memprediksi dukungan manajemen risiko berdasarkan faktor sikap manajemen. Persamaan regresi yang signifikan ditemukan dengan $\mathrm{F}(1,110)=$ 131,051, $\mathrm{P}<0,001$ dan $\mathrm{R} 2=0.544$. Persamaan regresi untuk dukungan manajemen risiko adalah 1,206 + 0,667 (avgB), di mana avgB adalah sikap manajemen terhadap manajemen risiko. Dukungan manajemen risiko meningkat sebesar 0,667 (dari skala 5) untuk setiap kenaikan nilai dari sikap manajemen. Sikap manajemen terhadap manajemen risiko adalah prediktor yang signifikan untuk dukungan manajemen risiko. Dengan demikian, sikap secara signifikan mempengaruhi dukungan dan kriteria kedua terpenuhi.

Pengujian yang ketiga adalah hasil output setelah data diolah menggunakan SPSS untuk menyelesaikan persamaan regresi sikap (AvgB) dan dukungan (AvgC) terhadap kinerja manajemen risiko (TotD). Regresi linear digunakan untuk memprediksi kinerja manajemen risiko berdasarkan faktor sikap manajemen dan dukungan manajemen. Persamaan regresi yang signifikan ditemukan dengan $\mathrm{F}(2,109)=164,43, \mathrm{P}<0,001$ dan $\mathrm{R} 2=$ 0.751. Persamaan regresi untuk kinerja manajemen risiko adalah $1,105+1,069$ (avgC), di mana avgC adalah dukungan manajemen terhadap manajemen risiko. Dukungan manajemen risiko meningkat sebesar 0,1069 (dari skala 5) untuk setiap kenaikan nilai dari sikap manajemen. Dukungan manajemen adalah prediktor yang signifikan terhadap kinerja manajemen risiko jika digabungkan, namun sikap manajemen adalah prediktor yang tidak signifikan terhadap kinerja manajemen risiko jika digabungkan. Dengan demikian, dukungan secara signifikan mempengaruhi kinerja manajemen risiko dan sikap tidak 
mempengaruhi kinerja manajemen risiko, sehingga kriteria ketiga terpenuhi.

Secara sederhana, hasil ketiga analisis regresi tersebut dapat digambarkan pada gambar 4 dan 5 .

Dikarenakan ketiga kriteria adanya variabel mediator terpenuhi, ditambah lagi efek sikap ke kinerja manajemen risiko menjadi tidak signifikan ketika variabel dukungan dimasukan ke analisis, maka terbukti bahwa dukungan menjadi mediator hubungan antara sikap dengan kinerja manajemen risiko.

Dari gambar 4 dan 5, dapat ketahui juga efek total sikap terhadap kinerja manajemen risiko sebesar 0,669, efek langsung sikap terhadap kinerja manajemen risiko sebesar 0,067 dan efek tidak langsung sikap terhadap kinerja manajemen risiko sebesar $0,737 \mathrm{x}$ $0,816=0,6014$. Efek total merupakan penjumlahan dari efek langsung ditambah efek tidak langsung.

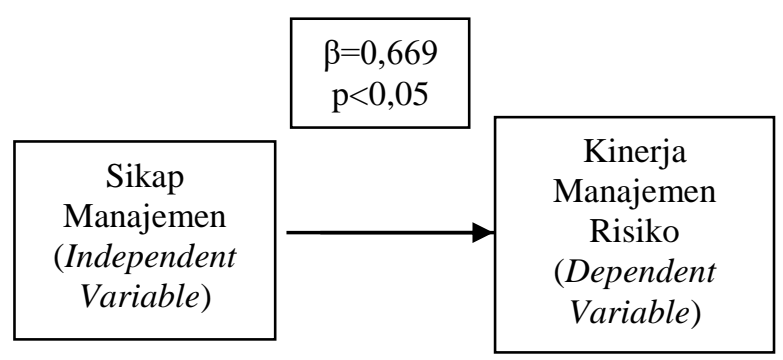

Gambar 4. Analisis Regresi Tanpa Mediator

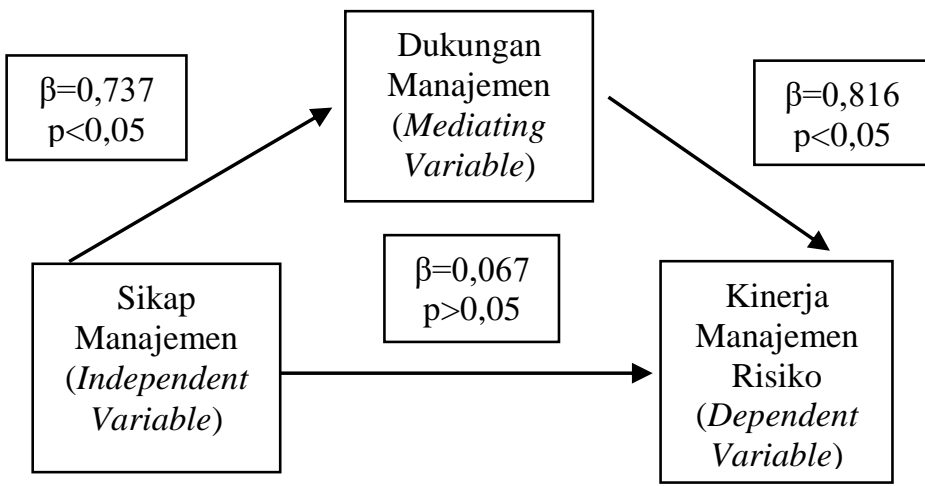

Gambar 5. Analisis Regresi Dengan Mediator

Adanya peran mediator juga dapat dilihat dari signifikansi efek tidak langsung. Untuk melihat besarnya pengaruh tidak langsung dan menguji signifikansinya, dapat dilakukan dengan Sobel test. Perhitungan dengan Sobel test menghendaki asumsi subjek yang besar dan data terdistribusi normal (Preacher dan Hayes, 2004). Kalkulasi menggunakan Sobel test dapat dilakukan secara online dengan mengakses link ini http://quantpsy.org/sobel/sobel.htm. Tampilan dari hasil perhitungan adalah sebagai berikut: 


\begin{tabular}{|l|l|l|l|l|}
\hline \multicolumn{1}{|c|}{ Input: } & & \multicolumn{1}{c|}{ Test statistic: } & p-value: \\
$t_{\mathrm{a}} 11.448$ & Sobel test: & 8.12659136 & 0 \\
\hline$t_{\mathrm{b}} 11.538$ & Aroian test: & 8.11125422 & 0 \\
\hline & & Goodman test: & 8.14201582 & 0 \\
\hline & & Reset all & \multicolumn{2}{|c|}{ Calculate } \\
\hline
\end{tabular}

Gambar 6. Hasil Uji Sobel Test

Gambar di atas merupakan hasil perhitungan Sobel test yang akhirnya diperoleh nilai test statistik sebesar 8,127 dan $\mathrm{p}<0,01$. Dengan demikian dapat disimpulkan bahwa dukungan manajemen memediasi hubungan antara sikap dan kinerja manajemen risiko. Dalam meningkatkan kinerja manajemen risiko, sikap meningkatkan dukungan terlebih dahulu sebelum meningkatkan kinerja manajemen risiko. Kemudian dikarenakan pengaruh sikap ke kinerja manajemen risiko menurun mendekati nol setelah memasukkan dukungan ke persamaan regresi (atau tidak signifikan), maka terjadi mediasi sempurna (perfect mediation).

\section{KESIMPULAN DAN SARAN}

Tujuan utama dari penelitian ini adalah penulis ingin melihat efek moderasi dari sikap pada dukungan manajemen terhadap kinerja manajemen risiko dikarenakan belum adanya penelitian yang melihat akan hal ini. Hasil yang didapatkan dari tujuan utama tersebut adalah bahwa sikap ternyata tidak dapat memoderasi dukungan terhadap kinerja manajemen risiko. Hasil lain yang ditemukan oleh penulis berdasarkan teori yang ada adalah dukungan menjadi variabel mediator antara sikap terhadap kinerja manajemen risiko. Kemudian dikarenakan pengaruh sikap ke kinerja manajemen risiko menurun mendekati nol setelah memasukkan dukungan ke persamaan regresi (atau tidak signifikan), maka terjadi mediasi sempurna (perfect mediation). Pemaparan temuan lain pada penelitian ini tidak didukung dengan penemuan pada penelitian-penelitian sebelumnya. Penulis tidak menemukan jurnal penelitian sebelumnya yang membahas dukungan manajemen sebagai mediator dari sikap manajemen ke kinerja manajemen risiko, namun penulis menemukan teori bahwa dukungan (tindakan) muncul setelah adanya sikap. Berbekal teori ini, penulis mencoba mengetahui dan membuktikan efek dukungan sebagai variabel mediator antara sikap terhadap kinerja manajemen risiko. Penemuan lain yang didapatkan penulis adalah bahwa pada penelitian-penelitian terdahulu, Beasley dkk (2015) menjadikan sikap dan dukungan manajemen sebagai satu kesatuan variabel. 
Salah satu penelitian yang mengambil dukungan manajemen sebagai efek mediasi dilakukan oleh Togok (2016) dan Hazan (2019). Namun mereka menjadikan budaya perusahaan sebagai variabel independen yang dijembatani oleh dukungan manajemen. Penelitian ini juga menemukan bahwa tidak adanya perbedaan yang signifikan antara ukuran perusahaan dengan kinerja manajemen risiko. Hal ini berbeda dengan apa yang ditemukan dari jurnal-jurnal sebelumnya dari Beasley dkk (2005), Beasley dkk (2015), Masmoudi (2018), Sprčić (2017). Penelitian sebelumnya berkesimpulan bahwa perusahaan dengan ukuran yang lebih besar akan memiliki kinerja manajemen risiko yang lebih baik dibandingkan perusahaan pada skala kecil atau menengah. Perusahaan yang besar akan memiliki risiko yang lebih banyak oleh karena itu dibutuhkan manajemen risiko yang lebih baik. Dari segi ukuran perusahaan, nilai dari kinerja manajemen risiko tersebar dengan baik, sebagian besar berada pada level sangat baik, sehingga sulit menemukan perbedaan yang signifikan antara ukuran perusahaan dan kinerja manajemen risiko. Tidak adanya perbedaan yang signifikan antara bidang usaha perusahaan dengan kinerja manajemen risiko.
Hal ini sesuai dengan temuan dari Beasley dkk (2005), Beasley dkk (2015), Masmoudi (2016). Pada penelitian-penelitian sebelumnya, terdapat bidang usaha yang dipisahkan secara khusus, yaitu finansial dan asuransi. Penelitian sebelumnya berkesimpulan bahwa perusahaan finansial dan asuransi memiliki tingkat kinerja manajemen risiko yang lebih baik, namun bidang usaha di luar finansial dan asuransi tidak ada perbedaan yang signifikan untuk kinerja manajemen risikonya. Hal ini juga didukung dengan data dari survey CRMS di mana rata-rata skor kinerja manajemen risiko adalah 4 dari maksimal 6 untuk jenis usaha di luar keuangan dan asuransi pada penelitian ini.

Berdasarkan hasil penelitian ini, maka implikasi bagi perusahaan-perusahaan yang ingin meningkatkan kinerja dari program manajemen risiko adalah dengan mengusahakan untuk meningkatkan sikap dan dukungan dari manajemen terhadap program manajemen risiko. Perusahaan dapat membuat kinerja manajemen risiko lebih efektif dengan terlebih dahulu menanamkan sikap yang positif (setuju/ suka) ke karyawan dengan cara adanya pertemuan rutin yang tidak perlu formal untuk saling bertukar pikiran terkait permasalahan di tempat kerja atau hal lain 
Apakah Sikap Mampu Memoderasi.....(Vincent Valerian, Yosia Moelyono \& Ronny Kountur)

yang sifatnya bimbingan konseling. Sikap

yang positif akan meningkatkan dukungan

yang dapat mempermudah pekerjaan dan

membuat kinerja manajemen risiko menjadi

lebih efektif. Selain itu, untuk meningkatkan

sikap dan dukungan terhadap kinerja

manajemen risiko, dapat dilakukan juga

dengan cara pengenalan dan pelatihan lebih

lanjut mengenai program manajemen risiko.
Berdasarkan hasil penelitian yang

diperoleh, maka saran yang diajukan,

penelitian ini dapat dilanjutkan dengan menguji variabel lain sebagai variabel yang berpengaruh terhadap kinerja manajemen risiko, seperti budaya perusahaan, sistem manajemen pada perusahaan, tingkat pendidikan manajemen dan variabel lain yang dapat disesuaikan dengan kebutuhan akan manajemen risiko. 


\section{DAFTAR PUSTAKA}

Ahmed, R., Mohamad, N. A. B., \& Ahmad, M. S. (2016). Effect of multidimensional top management support on project success: an empirical investigation. Quality \& Quantity, 50(1), 151-176.

Ahmed, R., \& Azmi bin Mohamad, N. (2016). Exploring the relationship between multi-dimensional top management support and project success: An international study. Engineering Management Journal, 28(1), 54-67.

Ajzen, I. (1991). The theory of planned behavior. Organizational behavior and human decision processes, 50(2), 179-211.

Ajzen, I., \& Fishbein, M. (1977). Attitude-behavior relations: A theoretical analysis and review of empirical research. Psychological bulletin, 84(5), 888.

Amalia, Dina (21 Desember 2017). Jenis-Jenis Perusahaan yang Ada di Indonesia. Diakses 2 November 2018, dari https://www.jurnal.id/en/blog/2017/jenis-jenis-perusahaan-yang-ada-diindonesia

Arena, M., Arnaboldi, M., \& Azzone, G. (2010). The organizational dynamics of enterprise risk management. Accounting, Organizations and Society, 35(7), 659-675.

Azwar, Saifuddin. (2008). Reliabilitas dan Validitas. Yogyakarta: Pustaka Belajar.

Baron, R. M., \& Kenny, D. A. (1986). The moderator-mediator variable distinction in social psychological research: Conceptual, strategic, and statistical considerations. Journal of personality and social psychology, 51, 1173-1182.

Beasley, M. S., Clune, R., \& Hermanson, D. R. (2005). Enterprise risk management: An empirical analysis of factors associated with the extent of implementation. Journal of accounting and public policy, 24(6), 521-531.

Beasley, M., Branson, B., \& Pagach, D. (2015). An analysis of the maturity and strategic impact of investments in ERM. Journal of Accounting and Public Policy, 34(3), 219-243. https://doi.org/10.1016/j.jaccpubpol.2015.01.001.

Berg, H. P. (2010). Risk management: procedures, methods and experiences. Reliability: Theory \& Applications, 5(2 (17)). 
Boonstra, A. (2013). How do top managers support strategic information system projects and why do they sometimes withhold this support?. International Journal of Project Management, 31(4), 498-512.

https://doi.org/10.1016/j.ijproman.2012.09.013.

Burnes, B., \& James, H. (1995). Culture, cognitive dissonance and the management of change. International Journal of Operations \& Production Management, 15(8), 14-33.

BusinessDictionary.com. Diakses 2 November 2018 dari BusinessDictionary.com website: http://www.businessdictionary.com/definition/risk.html

Deck, S. C. (2015). Enterprise risk management at higher education institutions: How management concepts support its implementation (Order No. 10020370). Available from ABI/INFORM Collection. (1768256556). Retrieved from

https://search.proquest.com/docview/1768256556?accountid=130508

Dewi, S. A. N. T., \& Dwirandra, A. A. N. B. (2013). Pengaruh Dukungan Manajemen Puncak, Kualitas Sistem, Kualitas Informasi, Pengguna Aktual dan Kepuasan Pengguna terhadap Implementasi Sistem Informasi Keuangan Daerah di Kota Denpasar. E-Jurnal Akuntansi, 196214.

Demidenko, E., \& McNutt, P. (2010). The ethics of enterprise risk management as a key component of corporate governance. International Journal of Social Economics, 37(10), 802-815.

Djohanputro, Bramantyo. (2018). Manajemen Risiko Korporat Terintegrasi. Jakarta : PPM.

Dong, L., Neufeld, D., \& Higgins, C. (2009). Top management support of enterprise systems implementations. Journal of Information technology, 24(1), 55-80.

Enterprise Risk Management-Integrated Framework. (2004). Committee of Sponsoring Organizations of the Treadway Commission (COSO). Diakses tanggal 2 November 2018 dari https://www.coso.org/Documents/COSO-ERM-Executive-Summary.pdf

Ehsani, M., Izadi, B., Yoon, Y. J., Cho, K. M., Koozechian, H., \& Tojari, F. (2013). An investigation of the effect of fan relationship management factors on fan lifetime value. Asian Social Science, 9(4), 248. 
Evalarasati10 (8 April 2015). PENGERTIAN PENANAMAN MODAL ASING (PMA), PENANAMAN MODAL DALAM NEGERI (PMDN), DAN JOINT VENTURE. Diakses tanggal 2 November 2018 dari https://evalarasati10.wordpress.com/2015/04/08/pengertianpenanaman-modal-asing-pma-penanaman-modal-dalam-negeri-pmdn-dan-joint-venture/

Farrell, M., \& Gallagher, R. (2015). The valuation implications of enterprise risk management maturity. Journal of Risk and Insurance, 82(3), 625-657. https://doi.org/10.1111/jori.12035.

Festinger, L. (1962). A theory of cognitive dissonance (Vol. 2). Stanford university press.

Fuadi, Munir (2003). Perseroan Terbatas Paradigma Baru. Bandung: Citra Aditya Bakti.

Gordon, L. A., Loeb, M. P., \& Tseng, C. Y. (2009). Enterprise risk management and firm performance: A contingency perspective. Journal of Accounting and Public Policy, 28(4), 301327.

Hartono, S. (1974). Masalah-masalah dalam joint ventures antara modal asing dan modal Indonesia. Bandung: Alumni.

Hazan, M. Faharizan, Ahmad Shukri Yazid (2019). The Mediating Effect of Top Management Support on the Relationship between Organizational Culture and Enterprise Risk Management Effectiveness among Malaysian Public Listed Companies. Research Journal of Finance and Accounting. 10 (2). 103-111

HSE Definitions. mfryer.com. Diakses 2 November 2018 dari http://www.mfryer.com/p033.htm

ISO GUIDE 73 (2009). Risk Management terminology. Swiss, Geneva: International Organization for Standardisation.

Industri Besar dan Sedang. Diakses 2 November 2018 dari https://www.bps.go.id/subject/9/industribesar-dan-sedang.html

Istijanto. (2009). Aplikasi Praktis Riset Pemasaran, Edisi Revisi. Jakarta: Gramedia.

Kanchu, T., \& Kumar, M. M. (2013). Risk Management in Banking Sector-an Empirical Study. International Journal of Marketing, Financial Services \& Management Research, 2(2), 145-158.

Kane, B., Crawford, J., \& Grant, D. (1999). Barriers to effective HRM. International Journal of Manpower, 20(8), 494-515. Retrieved from 


\section{https://search.proquest.com/docview/231895615?accountid=130508}

Katz, D. (1960). The functional approach to the study of attitudes. Public opinion quarterly, 24(2), $163-204$

Kelley, C. A., \& Young, J. E. (1983). Is your small business ready for planning? Journal of Small Business Management (Pre-1986), 21(000001), 28. Retrieved from https://search.proquest.com/docview/210753804?accountid=130508

Kleffner, A. E., Lee, R. B., \& McGannon, B. (2003). The effect of corporate governance on the use of enterprise risk management: Evidence from Canada. Risk Management and Insurance Review, $6(1), 53-73$.

Kountur, Ronny (2008). Mudah memahami manajemen risiko perusahaan. Jakarta: PPM

Lai, Fong-Woon \& A. Samad, Fazilah. (2010). Enterprise Risk Management Framework and The Empirical Determinants of Its Implementation. Paper presented at International Conference on Business and Economics Research.

Loonam, J. A., \& McDonagh, J. (2005). Exploring top management support for the introduction of enterprise information systems: a literature review. Irish Journal of Management, 26(1), 163.

Mahoney, M. L. (2011). An examination of the determinants of top management support of information technology projects (Order No. 3461886). Available from ABI/INFORM Collection. (881293382). Retrieved from https://search.proquest.com/docview/881293382?accountid=130508

MASMOUDI, S. M., \& BEN ARAB, S. D. (2018). Determinants of ERM Implementation: The Case of Tunisian Companies. Journal of Financial Reporting and Accounting, https://doi.org/10.1108/JFRA-05-2017-0044

McComb, S. A., Kennedy, D. M., Green, S. G., \& Compton, W. D. (2008). Project team effectiveness: the case for sufficient setup and top management involvement. Production Planning \& Control, 19(4), 301-311.

Mueller DJ. (1992). Mengukur Sikap Sosial, Pegangan untuk Peneliti dan Praktisi. Jakarta: Bumi Aksara. 
Muralidhar, K. (2010). Enterprise risk management in the middle east oil industry. International Journal of Energy Sector Management, 4(1), 59-86. doi:http://dx.doi.org/10.1108/17506221011033107

Nah, F. F. H., \& Delgado, S. (2006). Critical success factors for enterprise resource planning implementation and upgrade. Journal of Computer Information Systems, 46(5), 99-113.

Nah, F. F. H., Lee-Shang Lau, J., \& Kuang, J. (2001). Critical factors for successful implementation of enterprise systems. Business process management journal, 7(3), 285-296.

Preacher, K. J and Hayes, A. F., 2004. SPSS and SAS Procedures for Estimating Indirect Effects in Simple Mediation Models. Behavior Research Methods, Instruments, \& Computers, 36 (4): 717-731. Psychonomic Society, Inc

Pujianto, Andi (16 Maret 2014). 5 Jenis badan usaha berdasarkan kegiatan usahanya. Diakses 2 November 2018, dari http://www.ekonomikontekstual.com/2014/03/5-jenis-badan-usahaberdasarkan-kegiatan-usahanya.html

RIMS Risk maturity model. Diakses tanggal 2 November 2018 dari https://www.rims.org/resources/ERM/Pages/RiskMaturityModel.aspx

Sprčić, D. M., Kožul, A., \& Pecina, E. (2017). Managers' Support-A Key Driver behind Enterprise Risk Management Maturity. Zagreb International Review of Economics and Business, 20(s1), 25-39.

Sekaran, Uma \& Bougie, Roger. (2017). Research Method for Business A Skill Building Approach 7th Edition. United Kingdom: John Wiley \& Sons Ltd.

Simamora, Bilson. (2002). Panduan Riset Perilaku Konsumen. Jakarta: Gramedia.

Singarimbun, Masri dan Sofyan Effendi. (1989). Metode Penelitian Survei, Edisi Revisi. Jakarta: LP3ES.

Solimun. (2011). Analisis Variabel Moderasi Dan Mediasi. Malang: Program Studi Statistika FMIPAUB.

Staehr, L. (2010). Understanding the role of managerial agency in achieving business benefits from ERP systems. Information systems journal, 20(3), 213-238.

Sugiyono. (2014). Metode Penelitian Kuantitatif Kualitatif dan R\&D. Bandung: Alfabeta. 
Sujoko, Efferin dkk. (2004). Metode Penelitian untuk Akuntansi. Jawa Timur: Bayumedia Publishing.

Susilo, L.J. and Kaho, V.R., (2010). Manajemen Risiko berbasis ISO 31000 untuk industri non perbankan. Jakarta: PPM.

Umar, Husein. (2002). Metode Riset Bisnis. Jakarta: Gramedia

Undang-undang no 19 tahun 2003 tentang Badang Usaha Milik Negara. Jakarta: Presiden Republik Indonesia.

Undang-Undang no 20 Tahun 2008 tentang Usaha Mikro Kecil dan Menengah (UMKM) Jakarta: Presiden Republik Indonesia.

Undang-undang no 25 tahun 2007 tentang penanaman modal. Jakarta: Presiden Republik Indonesia

Waweru, N., \& Kisaka, E. S. (2011). The Effect of Enterprise Risk Management Implementation on the Value of Companies Listed in the Nairobi Stock Exchange.

Yazid, A. S., Hussin, M. R., \& Daud, W. N. W. (2011). An examination of enterprise risk management (ERM) practices among the government-linked companies (GLCs) in Malaysia. International Business Research, 4(4), 94.

Young, R., \& Poon, S. (2013). Top management support—almost always necessary and sometimes sufficient for success: Findings from a fuzzy set analysis. International journal of project management, 31(7), 943-957.

Zhao, X., Hwang, B. G., \& Low, S. P. (2013). Critical success factors for enterprise risk management in Chinese construction companies. Construction Management and Economics, 31(12), 11991214. 